Acta Technologica Agriculturae 4

Nitra, Slovaca Universitas Agriculturae Nitriae, 2014, pp. 101-104

\title{
TECHNOLOGICAL LEVEL OF MACHINES IN PRODUCTION PROCESS OF SCREWS
}

\author{
Manuela INGALDI*1, Katarína LESTYÁNSZKA ŠKŮRKOVÁ \\ 'Czestochowa University of Technology, Poland \\ ${ }^{2}$ Slovak University of Technology in Bratislava, Slovak Republic
}

\begin{abstract}
The article focuses on analysing one of the elements of technological level in a company using the ABC method. The technological modernity of a machine used during the production process of screws was evaluated. In average, this machine was assigned the score 3.4, meaning that most parts of the machine were manufactured using more complex technologies requiring technical skills and knowledge, and many of them also with modern technologies. This means that the machine examined was quite modern.
\end{abstract}

Keywords: modernity, technology, $A B C$ method, screws

Proper understanding of requirements moves the organization towards a successful and long-term functioning on the market involving a quality management system. It has been a long time since quality was a privilege and domain of large organizations only because survival on the market is forcing organizations of all sizes to work on the quality management system and implement it in practice. The aim of the quality management system is also a long-term maintenance of a stable production process and thus the stability of production quality (Prístavka and Bujna, 2014).

Technology can be defined as the overall knowledge of the particular method of manufacturing products to achieve a certain industrial or service effect. Based on this definition, it may be concluded that the company must have an appropriate knowledge of their production in order to produce goods of sufficient quality that will find buyers on the market.

Many products require the use of certain technology, or can be manufactured by different technologies. Their choice depends on many factors such as technical, economic, social or cultural (e.g. cost, time, legislation, safety, comfort, etc.). Technology and the quality of products as well as the final result will be affected by the production equipment owned by the company, especially its modernity (Prusak et al., 2010; Konstanciak, 2012).

The objective of this article was to evaluate the technological level of the machine for manufacturing screws during the production process. Such an evaluation forms one part of evaluation of the company's technological level. The modernity of the machine was evaluated using the $A B C$ method.

\section{Definition of company}

The company $\mathrm{X}$ has its tradition; it has been on the market for 75 years. First, it was a trade company (established before the World War II), and then it was transformed into manufacturing and service, too. The experience that it has gained for this period gives the guarantee of solidity and quality of its products. Moreover, the qualified stuff and modern way of production make its clients satisfied with their choice.
The size and methods of technological processes help the company to react properly to the market and individual needs of its clients. The fact that the company tries to keep up with the latest news makes this company progressive. Moreover, a high level of production, the quality of products, competitive prices, and keeping deadlines contribute to the fact that it is a trustworthy and reliable partner.

The list of products contains:

- universal plugs,

- hammer drive plugs,

- frame plugs,

- plugs for lavatory devices,

- plugs for insulating materials,

- sleeve anchors,

- screws.

\section{Production process in company}

One of the most important elements determining the level of the technology owned by the company is a properly designed and managed production process. The important elements of this process are production machines and equipment, which largely affect the company's results and show the level of its modernity.

Figure 1 shows the technological process of screws production (Borkowski and Ulewicz, 2008). Before the material (wire) is used in the production process, its diameter, type and weight corresponding to the quantity of ordered screws must be checked. Then, it is transported from storage to the production hall.

The operations in the production process shown in Figure 1 are as follows:

I Storage of the coil with low-carbon wire (grade SAE 1006).

II Transport of the coil with the wire to the production hall using a forklift.

III Straightening the low-carbon wire using a forging machine Hilgeland $\mathrm{CHOO}$.

IV Forging the wire with the forging machine Hilgeland $\mathrm{CH} 00$, which means shaping the wire (consisting of crushing the material under the impact of a die block). 


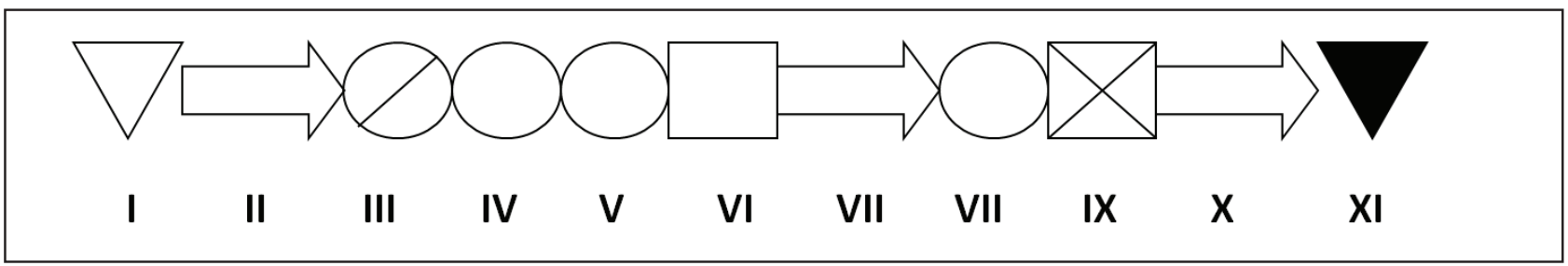

Figure 1 Production process of metal screws depicted technologically Source: own study

V Cutting the wire with the forging machine Hilgeland $\mathrm{CHOO}$ (operation takes place on the forging machine and is performed with scissors).

VI Inter-operation control of dimensions of forged and cut parts of screws.

VII Transporting the material with the forklift to a flat-die thread rolling machine Waterbury-Farrel.

VIII Roll threading with flat dies.

IX Final inspection of the correct screws size.

X Transporting of finished products to storage with the forklift.

XI Packaging and storage of finished products.

\section{Material and methods}

The $A B C$ method was used to evaluate the modernity of the machine and devices described by Borkowski et al. (2006), Kardas (2010), Selejdak et al. (2010), Borkowski and Ulewicz (2009), and Corejova and Borkowski (2004). This method, also called as Pareto-Lorenz method or the 80-20 rule, belongs to the methods that determine actions aimed at improvement of processes levels and quality characteristics of material goods and services. This analysis is based on the principle according to which several segments marked with the letter A can be divided into each group, which pre-determines the results to a great extent. The parts of a main subassembly A appear at the beginning of the system, and the parts of a collateral subassembly $C$ appear at the end of the system. The parts of a supportive subassembly $B$ are located in the middle of the system.

Evaluations are made on the basis of Parker's five-point scale:

Level 1 - machine parts manufactured using craft technologies;
Level 2 -machine parts manufactured with unchanging technologies used for years;

Level 3 - machine parts manufactured with more complex technologies requiring technical skills and knowledge;

Level 4 - machine parts manufactured with modern technologies;

Level 5 - machine parts manufactured with the most modern, unique technologies that are unknown for other producers.

The article analyses the modernity of the machine used in the manufacturing process of screws in the research company. All the parts of the machine were divided into three groups - the parts of the main subassembly $A$, the parts of the supportive subassembly $B$, and the parts of the collateral subassembly $C$. Then, each of these parts was evaluated using the previously described Parker's five-point scale.

The graphical interpretation of results was presented using a histogram, showing differences in evaluations. Pie charts demonstrate the graphical summary of percentage shares of individual levels for each assembly. The final results of the $A B C$ method for the whole machine were shown as percentage shares of each level in the form of bars, and accumulated shares in the form of linear function.

\section{Results and discussion}

The flat-die thread rolling machine Waterbury-Farrel was chosen for research in the production process. It is used for forming the material by applying pressure with rolls. The efficiency of this machine is 100 pcs $\mathrm{min}^{-1}$. The machine was manufactured in 1999 and is presented in Figure 2.

The evaluation of modernity level in individual parts of the machine is presented in Table 1.

Figure 3 graphically illustrates the modernity level of the machine. Figure 4 shows the structure of the

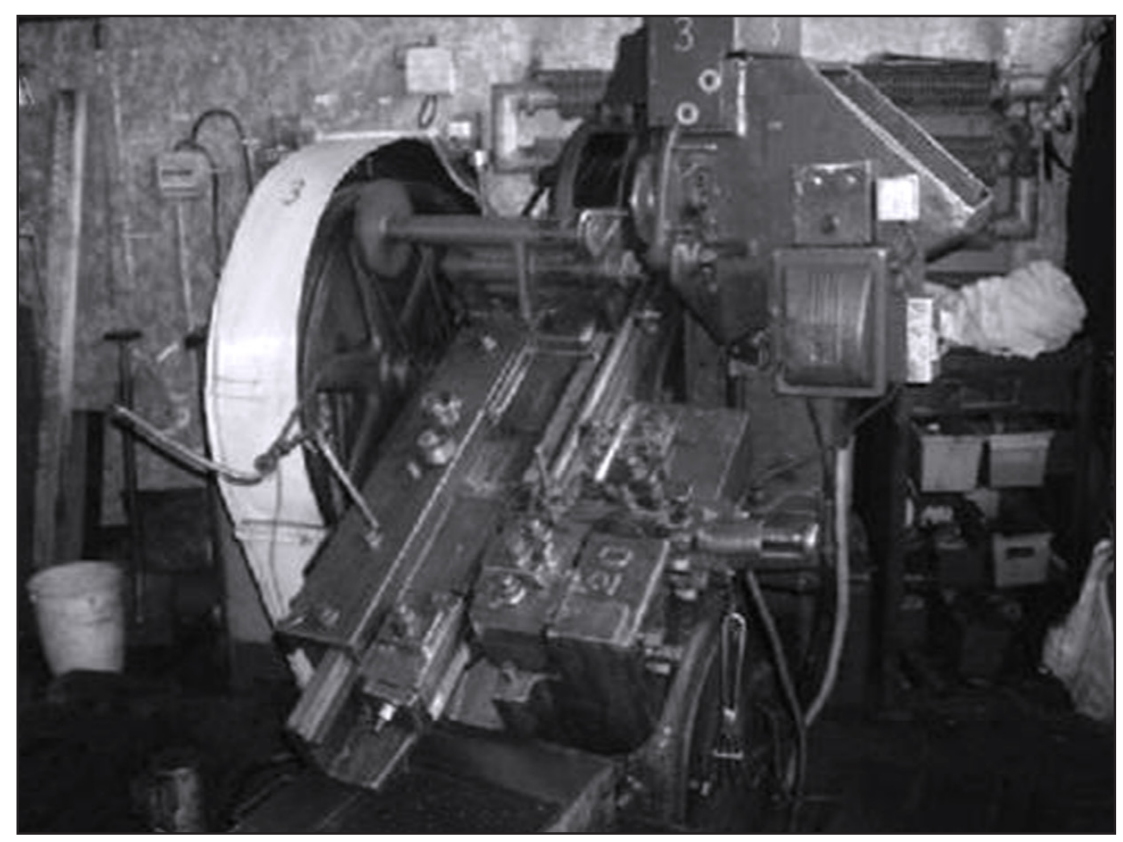

Figure 2 Flat-die thread rolling machine Waterbury-Farrel used in the company X 
Table 1 Evaluation of modernity level in the parts of the flat-die thread rolling machine Waterbury-Farrel

\begin{tabular}{|l||c|c|}
\hline No. & Parts of main subassembly A & Evaluation \\
\hline \hline A1 & Engine power & 3 \\
\hline A2 & Control system & 4 \\
\hline A3 & System settings & 4 \\
\hline A4 & Working rolls & 4 \\
\hline A5 & Control panel & 4 \\
\hline A6 & Vibratory feed mechanism & 5 \\
\hline A7 & Speed control & 3 \\
\hline A8 & Working rolling stand & 4 \\
\hline Average & & 3.9 \\
\hline \multicolumn{2}{||}{ Parts of supportive subassembly B } \\
\hline \hline B1 & Guides & 3 \\
\hline B2 & Hydraulic system & 5 \\
\hline B3 & Rolling stand & 4 \\
\hline B4 & Supportive system & 3 \\
\hline B5 & Clutch & 3 \\
\hline B6 & Toothed gear & 2 \\
\hline
\end{tabular}

\begin{tabular}{|l||c|c|}
\hline B7 & Flywheel & 2 \\
\hline B8 & Alarm of the distance between rolls & 3 \\
\hline B9 & Annular drawing machine & 5 \\
\hline B10 & Single-stage drawing machine & 5 \\
\hline B11 & Jaws & 4 \\
\hline Average & \multicolumn{2}{|c|}{ Parts of collateral subassembly C } \\
\hline \multicolumn{2}{|c|}{ Bumper } \\
\hline \hline C1 & Lubrication system & 3.5 \\
\hline C2 & Suds pump & 5 \\
\hline C3 & Machine structure & 2 \\
\hline C4 & Shields & 4 \\
\hline C5 & Foundation & 1 \\
\hline C6 & Tools warehouse & 2 \\
\hline C7 & 2.6 & 1 \\
\hline C8 & Manual system of tool change & 2 \\
\hline Average &
\end{tabular}

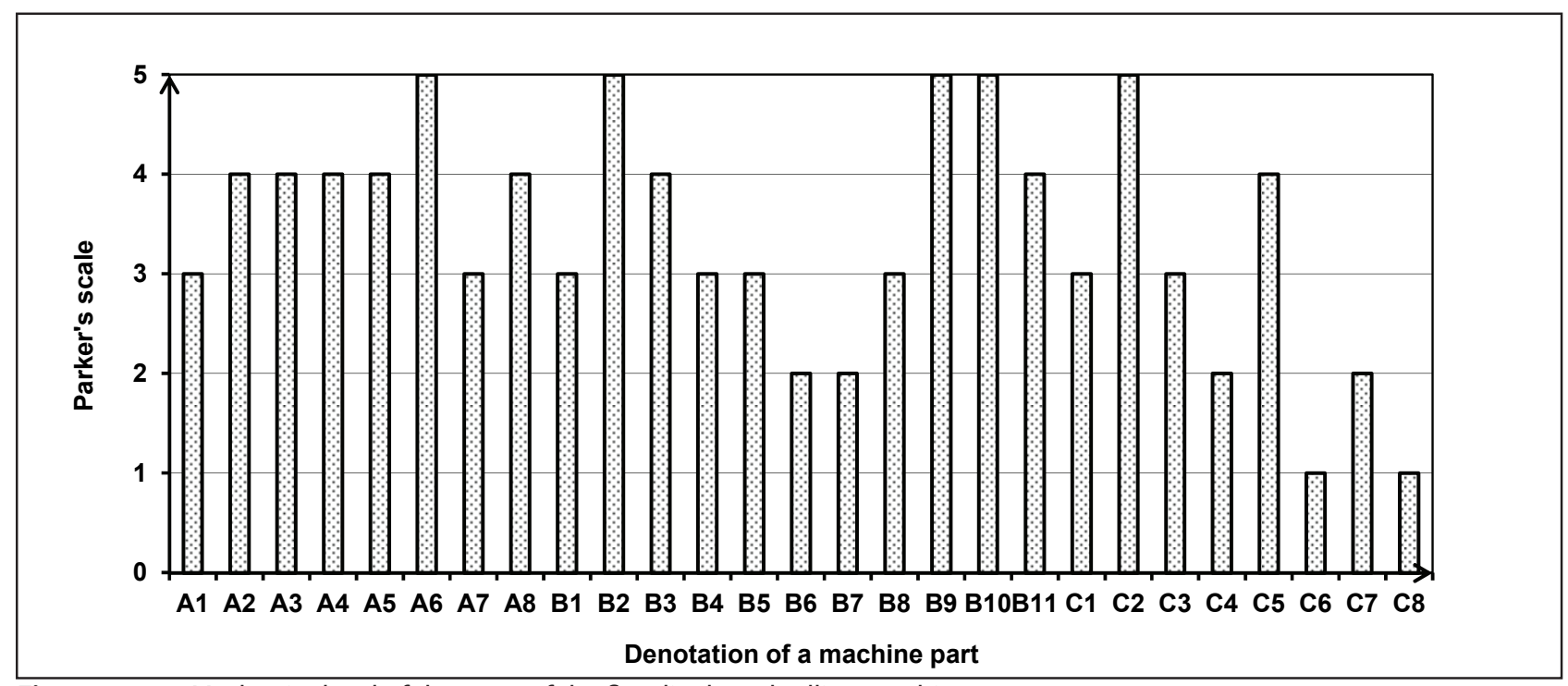

Figure $3 \quad$ Modernity level of the parts of the flat-die thread rolling machine Source: own study
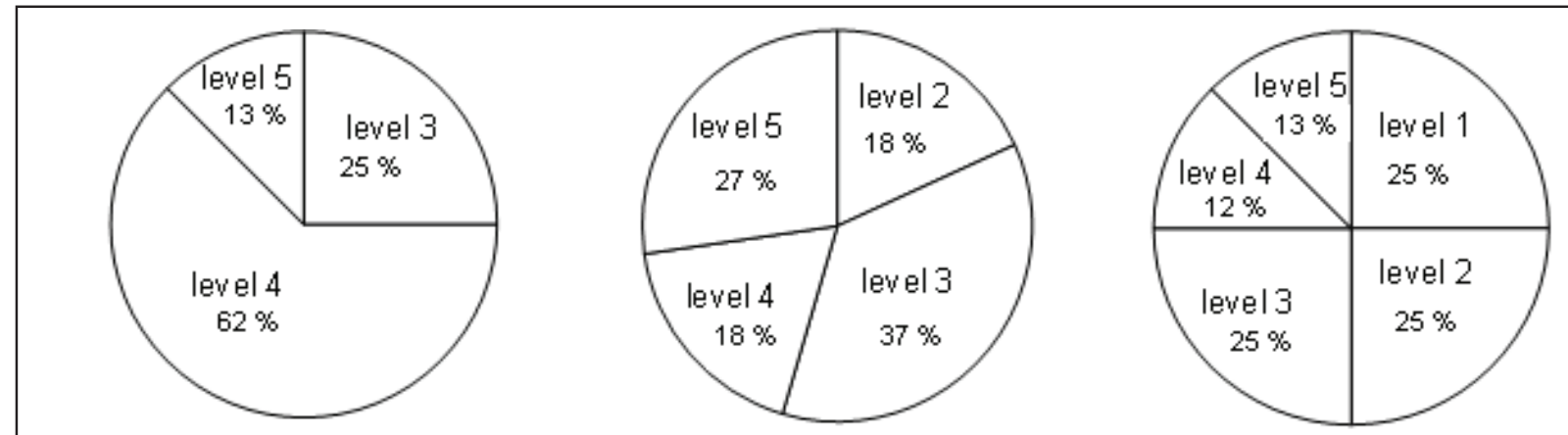

Figure 4 Modernity structure of the subassemblies of the flat-die thread rolling machine in: a) main subassembly, b) supportive subassembly, c) collateral subassembly Source: own study 


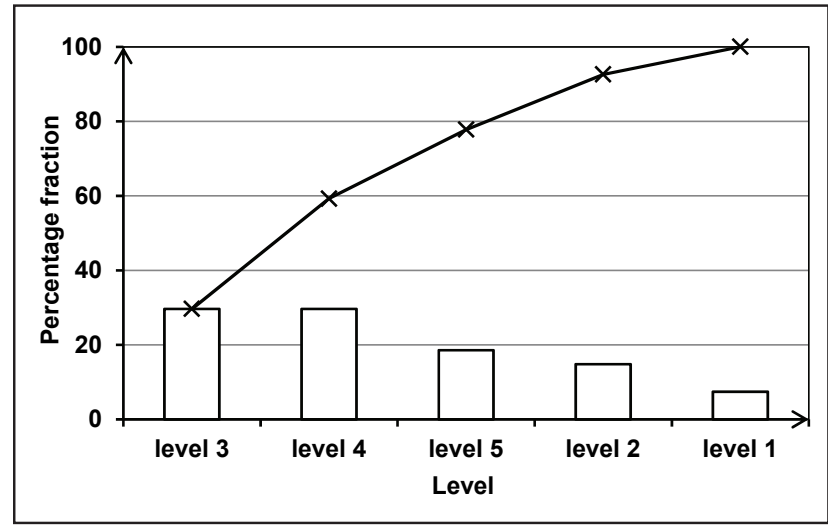

Figure $5 \quad A B C$ analysis of modernity level of the flat-die thread rolling machine

Source: own study

machine modernity level, taking into account the individual subassemblies. Figure 5 presents the final result of the $A B C$ analysis.

The individual parts of the flat-die thread rolling machine were described as follows:

- The parts of the main subassembly A: $25 \%$ is at level 3, $62 \%$ is at level $4,13 \%$ is at level 5 . Therefore, 4 was the most often given evaluation (five times). The vibratory feed mechanism was the part evaluated with the highest number (level 5), while the engine power and speed control were assigned the lowest number (3) in the main subassembly A. This group reached the highest average evaluation (3.9).

- The parts of the supportive subassembly B: $18 \%$ is at level $2,37 \%$ is at level $3,18 \%$ is at level $4,27 \%$ is at level 5 Therefore, 3 was the most often given evaluation (four times). The annular drawing machine and single-stage drawing machine were assigned the highest number (level 5), while the toothed gear and flywheel were evaluated with the lowest number (2) in the supportive subassembly $B$.

- The parts of the collateral subassembly C: $25 \%$ is at level 1 , $25 \%$ is at level $2,25 \%$ is at level $3,12 \%$ is at level 4 , and $13 \%$ is at level 5 . No evaluation could be characterized as being given more often. The lubrication system was assigned the highest number (level 5), while the foundation and tools warehouse were evaluated with the lowest number (1) in the collateral subassembly $C$. This group had the lowest average evaluation (2.6)

Summing up the results of the $A B C$ method by applying the five-point Parker's scale to the individual parts of the flat-die thread rolling machine, it can be seen that the largest groups of the flat-die thread rolling machine parts were 3 or 4 (almost $60 \%$ ). It means that these two groups decide about machine modernity. Almost $20 \%$ of the parts were manufactured with the most modern, unique technologies unknown to other producers (level 5). Only $20 \%$ of the parts were manufactured using craft technologies or unchanging technologies used for years (level 1 and 2).

In average, the machine was evaluated by number 3.4, meaning that most parts of the machine were manufactured with more complex technologies requiring technical skills and knowledge, and many of them also with modern technologies.

\section{Conclusion}

The main objective of the article was to evaluate the technological modernity of the machine in the production process of screws using the $A B C$ method. This analysis is part of the evaluation of the company's technological strategic position.

The research company is known on the market with 75-year traditions in production. It manufactures various types of plugs, sleeve anchors and screws.

According to the $A B C$ method, the machine was evaluated in average as having been assigned the score 3.4. It means that most parts of the machine were manufactured with more complex technologies requiring technical skills and knowledge, and many of them also with modern technologies. It can be concluded that the equipment of the company is sufficiently modern despite its age. In the near future, the company will probably have to invest in a new device for threading; however, it is at an appropriate level for now.

\section{References}

BORKOWSKI, S. - SELEJDAK, J. - SALAMON, S. 2006. Efektywność eksploatacji maszyn i urządzeń. Częstochowa : Wyd. WZP Częst, 2006.

BORKOWSKI, S. - ULEWICZ, R. 2009. Instrumenty doskonalenia procesów produkcyjnych. Warszawa : Wyd. PTM, 2009.

BORKOWSKI, S. - ULEWICZ, R. 2008. Zarządzanie produkcją. Systemy produkcyjne. Sosnowiec : Pub. Humanitas, 2008.

COREJOVA, T. - BORKOWSKI, S. 2004. Instrumenty rozwiązywania problemów w zarządzaniu. Sosnowiec : Wyd. Wyż. Szkoły Zarz. i Marketingu w Sosnowcu, 2004.

KARDAS, E. 2010. Wykorzystanie metody ABC do analizy materiałów w wybranym zakładzie wielkopiecowym. In Logistyka, 2010, no. 4, pp. 64-68.

KONSTANCIAK, M. 2012. Analysis of technological strategies on the example of production of tramway wheels. In Archives of Materials Science and Engineering, vol. 57, 2012, no. 2, pp. 69-7 coś jeszcze

MATERIALS FROM THE RESEARCH COMPANY.

PRISTAVKA, M. - BUJNA, M. 2014. Monitoring the capability of production equipment in organization. In Acta Technologica Agriculturae, vol. 17, 2014, no. 2, pp. 39-43.

PRUSAK, R. - KARDAS, E. - SKUZA, Z. 2010. Analiza strategiczna w procesie pozycjonowania przedsiębiorstwa na rynku. In Produkcja i zarządzanie w hutnictwie. Ed. Budzik R. Publisher WIPMiFS, Politechniki Częstochowskiej, Seria: Metalurgia, 2010, no. 54, pp. 135-138.

SELEJDAK, J. - KONSTANCIAK, M. - MIELCZAREK, K. 2010. Chapter 3. Evaluation of technological efficiency and up-to-dateness of machines used in building industry. In Operating Efficiency and Machines Modernity. Ed. and Scientific Elaboration Borkowski, S. Selejdak, J. Publisher Endi Miletić, Sisak, 2010, pp. 33-46.

\section{Contact address:}

Manuela Ingaldi, Czestochowa University of Technology, Faculty of Management, Institute of Engineering Production, al. Armii Krajowej 19b, 42-200 Czestochowa, Poland, e-mail: manuela@gazeta.pl 